\title{
Potential of $\mathrm{N}_{2}$ Gas Flushing to Hinder Dairy-Associated Biofilm Formation and Extension
}

\author{
Patricia Munsch-Alatossava ${ }^{1 *}$ and Tapani Alatossava² \\ ${ }^{1}$ Independent Researcher, Helsinki, Finland, ${ }^{2}$ Department of Food and Nutrition, University of Helsinki, Helsinki, Finland
}

Worldwide, the dairy sector remains of vital importance for food production despite severe environmental constraints. The production and handling conditions of milk, a rich medium, promote inevitably the entrance of microbial contaminants, with notable impact on the quality and safety of raw milk and dairy products. Moreover, the persistence of high concentrations of microorganisms (especially bacteria and bacterial spores) in biofilms (BFs) present on dairy equipment or environments constitutes an additional major source of milk contamination from pre- to post-processing stages: in dairies, BFs represent a major concern regarding the risks of disease outbreaks and are often associated with significant economic losses. One consumption trend toward "raw or low-processed foods" combined with current trends in food production systems, which

OPEN ACCESS

Edited by:

Lin Lin,

Jiangsu University, China

Reviewed by:

levgeniia Ostrov,

Rutgers, The State University

of New Jersey, United States

Md Furkanur Rahaman Mizan, Chung-Ang University, South Korea

*Correspondence: Patricia Munsch-Alatossava patricia_munsch@yahoo.fr

Specialty section:

This article was submitted to Food Microbiology, a section of the journal Frontiers in Microbiology

Received: 18 May 2020 Accepted: 26 June 2020

Published: 28 July 2020

Citation:

Munsch-Alatossava $P$ and Alatossava T (2020) Potential of $\mathrm{N}_{2}$

Gas Flushing to Hinder Dairy-Associated Biofilm Formation and Extension.

Front. Microbiol. 11:1675. doi: 10.3389/fmicb.2020.01675 tend to have more automation and longer processing runs with simultaneously more stringent microbiological requirements, necessitate the implementation of new and obligatory sustainable strategies to respond to new challenges regarding food safety. Here, in light of studies, performed mainly with raw milk, that considered dominant "planktonic" conditions, we reexamine the changes triggered by cold storage alone or combined with nitrogen gas $\left(\mathrm{N}_{2}\right)$ flushing on bacterial populations and discuss how the observed benefits of the treatment could also contribute to limiting BF formation in dairies.

Keywords: cold chain, food spoilage, dairy, bacteria, biofilms, $\mathrm{N}_{2}$ gas flushing

\section{THE DAIRY SECTOR, BETWEEN PROSPECTS, AND CHALLENGES}

The economic importance of the dairy sector is obvious when considering the global milk output estimated at 843 million tons in 2018 (FAO, 2019), or the current projections that predict an increase by $1.7 \%$ per annum of the world milk production over the next decade 2019/2028 (OECDFAO, 2019). The EU, with a production of 172.2 million tons of milk in 2018 , represents a major player in the global dairy market as the dairy sector constitutes the second largest in terms of total agricultural output (Augère-Granier, 2018).

Food production systems face growing concerns related to climate change and greenhouse gas emissions, and the dairy sector is also urged to implement sustainable criteria from farms to dairies worldwide, such as to optimize the use of natural resources and reduce the environmental impact (Clay et al., 2020). Another important aspect concerns tremendous food spoilage: globally, onethird of all food produced for human consumption is lost or wasted. In Europe alone, 29 million tons of dairy products are lost or wasted every year; this loss represents a massive squandering of 
resources (land, water, energy, labor, and capital), including needless production of greenhouse gas emissions that promote global warming and climate change (FAO, 2015). Microbes, by overcoming hurdles applied for food preservation, also significantly contribute to food losses.

\section{SPECIFIC FEATURES OF MILK AND ITS PRESERVATION}

Milk, which supports the growth of newborn mammals, presents a spectrum and balance of the different components characteristic of each mammalian species and simultaneously carries nutritional components (lipids, proteins, carbohydrates (lactose), vitamins, and salts, etc.), protective functions (linked to the presence of antimicrobial elements), or regulatory functions (growth hormones, regulatory proteins, and bioactive lipids, etc.; Singh and Bennett, 2002; Tetra Pak, 2003; Walstra et al., 2006). The major components of fresh raw milk for bovines, the most important dairy husbandry animals in Europe, are detailed in Figure 1. Milk constitutes an example of a fat-inwater emulsion, where the fat fraction exists mostly as small globules dispersed in the milk plasma. Milk fat is characterized by a variety of more than 400 different fatty acids: among the 5 major types (listed in Figure 1), butyric and oleic acids are in a liquid state at room temperature (Taylor and Mac Gibbon, 2002; Tetra Pak, 2003). The milk fat globules are delimitated by an $8-10$-nm-thick membrane (milk fat globule membrane, MFGM) derived from the apical cell membrane of the Golgi apparatus and from membrane parts of the lactating cell added before exocytosis; the MFGM comprises layers of proteins, enzymes, and phospholipids (PLs) which constitute an essential part of this membrane (Tetra Pak, 2003; Singh and Gallier, 2017; Figure 1). Milk proteins are represented by soluble whey proteins and caseins (the dominant class), which exist as colloidal particles, casein micelles, in milk plasma (Figure 1); all caseins are phosphoproteins and the phosphate groups also bind large amounts of calcium (Singh and Bennett, 2002).

Irrespective of the environment or farm type, raw milk, due to its rich composition, remains a highly perishable medium that largely determines the quality and safety of fresh and processed dairy products. Milk produced in a healthy udder is believed to be virtually sterile. However, after withdrawal, depending on the production and environmental conditions, various contamination sources (water, silage, milking equipment, ambient air of the farm environment, etc.) promote the entrance of different types of microorganisms (viruses, bacteria, bacterial spores, and fungi) into raw milk. Given their roles as either beneficial or detrimental to humans, among all microbes, bacteria are of major importance. To preserve the quality and safety of raw milk, two options are recommended: in low-income countries, the activation of the lactoperoxidase system (LPS) is used to prevent excessive bacterial growth (FAO, 2005). In high-income countries, where efficient coldchain conditions exist, raw milk is chilled immediately after milking and kept at low temperatures until processing stages (European Parliament Directive, 2013).

\section{PERSISTING POPULARITY OF RAW MILK CONSUMPTION}

For the period 1993-2012, a total of 127 outbreaks, which were reported to the Centers for Disease Control and Prevention (CDC, United States) and lead to 1909 illnesses and 144 hospitalizations, were linked to the consumption of raw milk or raw milk-based products (ice cream, soft cheese, or yogurt). The belief that raw milk is healthier than pasteurized milk remains strong, and selling raw milk is legal in 30 states, though outbreaks are on the rise in the United States (Centers for Disease Control and Prevention, 2017). Despite the fact that reports regularly point to health risks linked to the consumption of raw milk or of dairy products made from raw milk, especially for vulnerable populations (children, older adults, pregnant woman, and people with a weakened immune system), a trend toward consumption of raw food with the "raw food diet" or "minimally processed food" products has tended to gain in popularity. Consumers neglect that dairy farms also constitute an important reservoir of food-borne pathogens (Verraes et al., 2015; Van Asselt et al., 2017).

In Europe, microbiological risks are more frequently encountered in dairy products than chemical or physical hazards: the public health risks related to drinking raw milk are mostly due to Campylobacter spp., Salmonella spp., Escherichia coli strains producing shigatoxin, Brucella melitensis, Mycobacterium bovis, and tick-borne encephalitis virus (EFSA, 2015). For the years 2009 to 2014, the Rapid Alert System Food and Feed notifications associated with food safety hazards in dairy products for the most part reported microbiological contamination: $76 \%$ of the cases incriminated pathogens (mainly Listeria monocytogenes, E. coli, and Salmonella), whereas $24 \%$ were related to spoilage microorganisms (Van Asselt et al., 2017).

\section{CHARACTERISTICS OF RAW MILK WITH A BACTERIAL LOAD OF $3 \cdot 10^{5} \mathrm{CFU} / \mathrm{ML}$ AT THE PROCESSING STAGE}

\section{Cold Storage-Triggered Changes}

For Europe, the recommendations stipulate that shortly after withdrawal, raw milk should be rapidly chilled and stored in farm tanks at temperatures below $8^{\circ} \mathrm{C}$ or at not more than $6^{\circ} \mathrm{C}$ in the case of daily versus not daily (typically every 2 nd day) collection, respectively, so that bacterial counts do not exceed $10^{5} \mathrm{cfu} / \mathrm{ml}$; subsequently, the cold-stored milk is transferred into an insulated tank of a truck before being routed, at a temperature that must not exceed $10^{\circ} \mathrm{C}$, to dairy silos; before processing at dairies, raw milk is further cold-stored so that the "total bacterial counts" do not exceed $3 \times 10^{5} \mathrm{cfu} / \mathrm{ml}$ (this legal "total bacterial counts" label corresponds to aerobic vegetative mesophilic types), as counts above this level are associated with defects in dairy products (Sorhaug and Stepaniak, 1997; European Parliament Directive, 2013).

To prevent the separation of skim milk and cream fractions during cold storage, raw milk is constantly subjected to agitation 


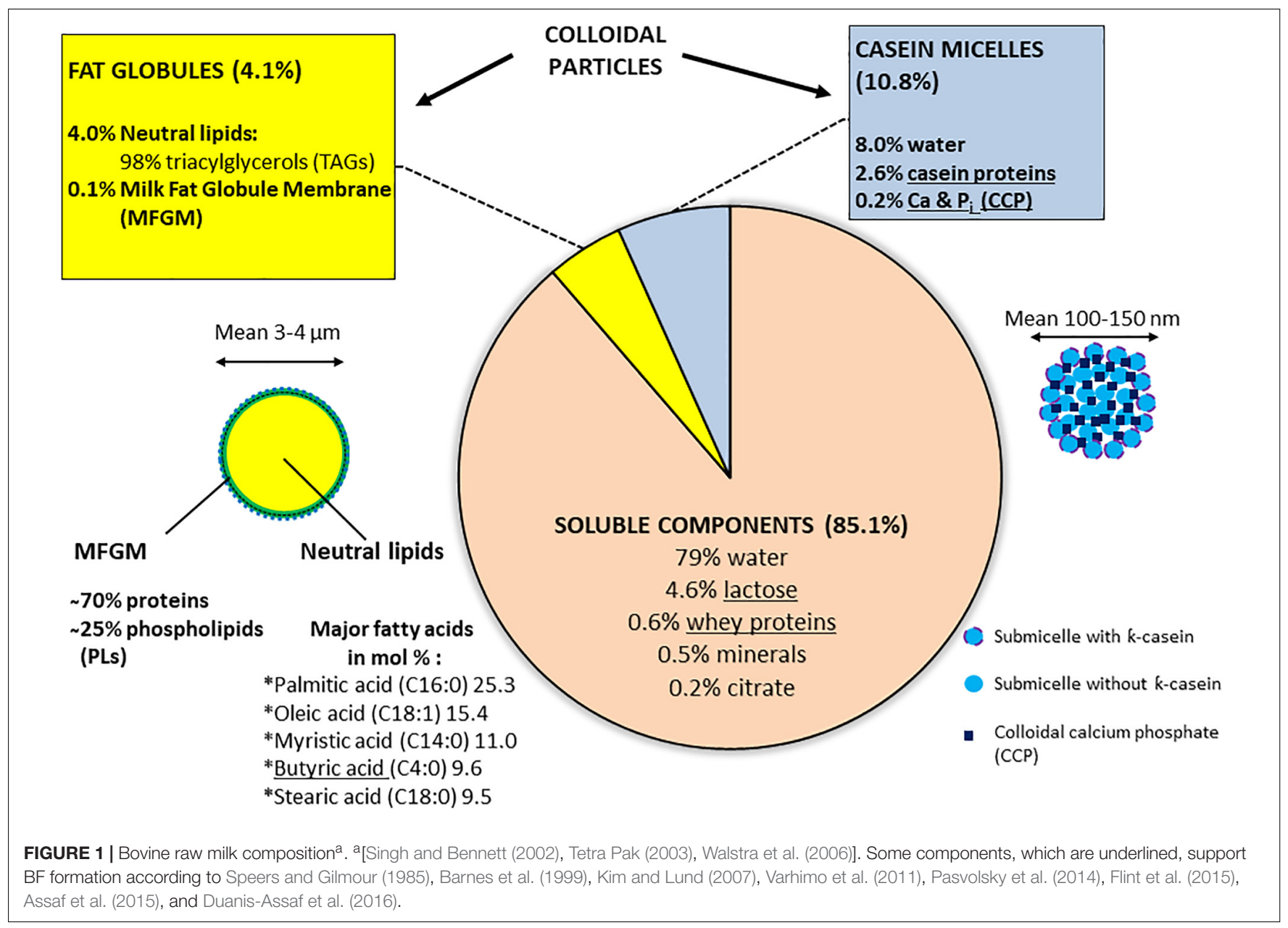

in tanks and silos; the concentrations of dissolved oxygen $\left(\mathrm{O}_{2}\right)$ and nitrogen $\left(\mathrm{N}_{2}\right)$ reach 0.6 and $0.16 \mathrm{mg} / 100 \mathrm{~g}$, respectively, in cold-stored bovine raw milk, whereas in the udder, the dissolved $\mathrm{O}_{2}$ level is approximately $0.15 \mathrm{mg} / 100 \mathrm{~g}$ (Tetra Pak, 2003; Walstra et al., 2006).

If the storage temperature is a critical factor, as illustrated by the growth inhibition of bacteria at temperatures of $4-5^{\circ} \mathrm{C}$ for a limited time period, the "time" factor is also of crucial importance, as slightly above $48 \mathrm{~h}$, these low temperatures are not sufficient to prevent the growth of cold-tolerant psychrotrophic bacteria (able to grow below $7^{\circ} \mathrm{C}$ ), of which the vast majority associated with food spoilage at refrigeration temperatures is constituted by aerobes or facultative anaerobes (Chambers, 2002; Tetra Pak, 2003; Jay et al., 2006). Dairy intensification, which has also entailed the replacement of many small local dairies by fewer but larger and more distant dairy industries, has increased the importance of the "time" factor. A recent report indicated that raw milk can be kept in refrigerated conditions for 3 to 5 days in a farm bulk tank before being delivered to dairy processing plants (Vithanage et al., 2016).

The dominant view is that, after withdrawal, bacterial genera vulnerable to low temperatures are outnumbered by others favored by cold-storage conditions: accordingly, gram-positive micrococci and streptococci are supplanted by gram-negative rods such as Pseudomonas, Acinetobacter, and Aeromonas; several studies have indicated that bacterial diversity decreases during cold storage; high-throughput sequencing has also revealed the presence of anaerobic taxonomic groups such as Bacteroides, for example, which are typically associated with gut microbiota (rather indicative of fecal contamination); moreover, even short-term storage periods lead to quick population changes (Chambers, 2002; Dogan and Boor, 2003; Raats et al., 2011; Quigley et al., 2013; Gschwendtner et al., 2016; Kable et al., 2016).

At the end of cold storage, raw milk undergoes various heat treatments (including pasteurization, UHT, etc.) which aim to eradicate pathogens and increase the shelf life of dairy products. Although most if not all contaminating bacteria (including psychrotrophs) will be destroyed, the same heat treatments activate various bacterial spores present in raw milk, which can germinate even at low temperature; these types are represented by Bacillus cereus, a common milk contaminant responsible for foodborne illness, or Bacillus spp. and Paenibacillus, the key microorganisms limiting the shelf life of fluid milks, whereas Clostridium tyrobutyricum is associated with spoilage of long-ripened cheeses (Tetra Pak, 2003; Stenfors Arnesen et al., 2008; Mato-Rodriguez and Alatossava, 2010; Ivy et al., 2012). 


\section{Bacterial Metabolism, Spoilage Features, and Antibiotic Resistance}

During cold storage, various primary and secondary bacterial metabolites are released in raw milk. For example, the presence of toxins (Verraes et al., 2015; Mylius et al., 2018), cyclic lipodepsipeptides (CLPs; Reybroeck et al., 2014), lysophospholipids (Keenan and Mather, 2002; Gallier et al., 2010; Munsch-Alatossava et al., 2018a), and autoinducers (Christensen et al., 2003; Lu et al., 2004) has been evidenced. If most bacterial cells and heat-labile compounds present in raw milk are inactivated by subsequent heat treatments, the risk that heat-stable metabolites may be displaced into dairy products cannot be excluded.

Normal bovine milk contains tens of indigenous enzymes: many are technologically significant as indicators of deterioration, thermal history, or mastitis infection (Fox, 2003). However, most enzymes associated with spoilage and «technological» complications, or failures are of bacterial origin. Psychrotrophic bacteria that thrive in cold-stored raw milk produce and excrete various spoilage enzymes such as proteases, lipases, and phospholipases (PLases), which target the different milk components; unfortunately, many of these enzymes show remarkable inherent heat stability as they withstand pasteurization or even UHT treatments (Cousin, 1982; Shah, 1994; Sorhaug and Stepaniak, 1997; Chambers, 2002; Dogan and Boor, 2003); one recent report indicated that over $30 \%$ of the investigated Pseudomonas strains retained residual lipase and protease activities after being subjected to $142^{\circ} \mathrm{C}$ for $4 \mathrm{~s}$ (Vithanage et al., 2016). These remaining enzymatic activities can subsequently hydrolyze original milk components, leading to bio/chemical, and physical changes in dairy products; excessive protease activities are associated with bitter flavor and gelation of fluid milk (Figure 2), whereas high levels of lipase promote the apparition of off-flavors or even hinder cheese production; additionally, PLases, by degrading the MFGM, will offer free access to native or bacterial lipases, promoting the hydrolysis of neutral lipids normally "stored" inside the fat globules (Chrisope and Marshall, 1976; Cousin, 1982; Deeth, 2002; Figure 1). Ultimately, in raw milk, lipolysis results in a drop in the $\mathrm{pH}$ and an increase in the content of free fatty acids (FFAs; Deeth, 2002; Tetra Pak, 2003). Altogether, an excess of bacterial enzymes reduces the shelf life and decreases the quality of dairy products. Combinations of higher temperatures for increased times would certainly lead to higher inactivation rates of these enzymes; however, such treatments would simultaneously promote the undesired denaturation of whey proteins (crucial, for example, for cheese manufacture), and the destruction of vitamins, with notable impact on both organoleptic and nutritional features of milk.

Food has also been identified as one main direct vehicle for the transmission of antibiotic-resistant bacteria from animals to humans and of antibiotic resistance (AR)-encoding genes carried by zoonotic bacteria (Sørum and L'Abbé Lund, 2002; Wichmann et al., 2014). Similarly, raw milk-associated psychrotrophs and mesophiles, which frequently exhibit spoilage features, also carry AR features; strangely enough, AR was most

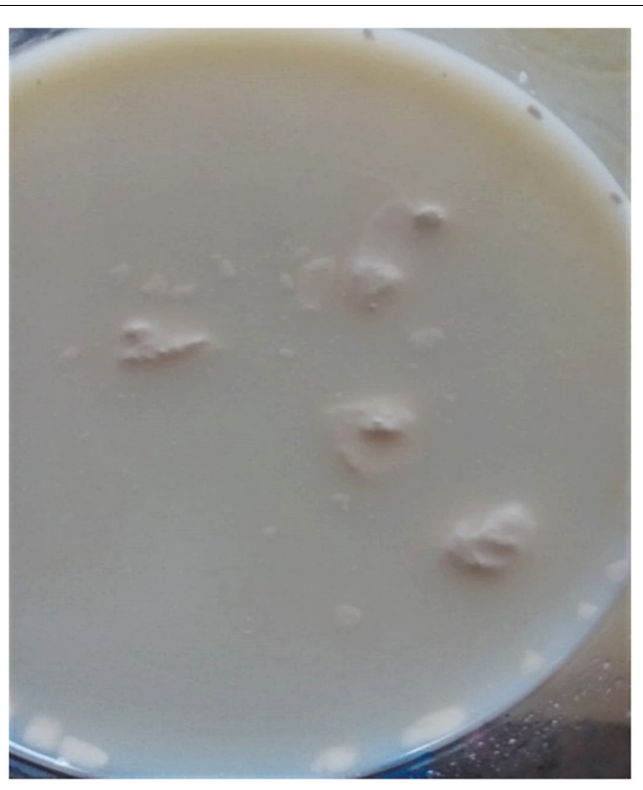

FIGURE 2 | Spoilage assessment by the consumer. The UHT milk (labeled best before 30.03.20) was purchased on 29.12.19 and opened on 30.12.19. The six bottles, belonging to the same pack, appeared perfectly sealed, and all presented the same defect: the numerous aggregates of variable sizes most likely result from proteolytic activity on casein micelles. Excessive thermoresistant protease activities may be due to raw milk-associated psychrotrophs or to deficiencies that occurred at any stage of the milk-processing chain, including the presence of BFs.

prevalent in both population types at a stage when the total bacterial counts reached approximately $10^{5} \mathrm{cfu} / \mathrm{ml}$; notably, the raw milk samples presented simultaneously significant amounts of multiresistant bacteria (Munsch-Alatossava and Alatossava, 2007; Munsch-Alatossava et al., 2012, 2017).

\section{QUORUM SENSING ALSO REGULATES THE EXPRESSION OF BACTERIAL SPOILAGE ENZYMES IN RAW MILK}

For gram-positive or gram-negative bacterial types, the cell density-dependent signaling system, or quorum sensing (QS) is involved in major functions/activities such as sporulation, competence, competition, the production of toxin, exopolymers, and extracellular DNA (eDNA), and virulence gene expression. QS also promotes biofilm formation, including the production of enzymes (Davies et al., 1998; Miller and Bassler, 2001; Papenfort and Bassler, 2016). The signaling compounds or autoinducers are of various types: gram-negative bacteria synthesize fatty-acid derivatives, $\mathrm{N}$-acyl-homoserine lactones (AHLs) also called AI-1, which mostly serve in intraspecies communication; both grampositive and gram-negative bacteria produce AI-2, a furanosyl borate diester or furanone derivative, considered the universal signaling molecule, that enables interspecies and intraspecies communication (Miller and Bassler, 2001; Smith et al., 2004; Papenfort and Bassler, 2016). 
Signaling compounds have also been isolated from foods (Smith et al., 2004; Skandamis and Nychas, 2012), including milk and dairy products: experiments have established that several hydrolytic enzymes produced by Serratia proteamaculans and involved in milk spoilage were regulated by QS (Christensen et al., 2003). Additionally, AHL production is a common trait of psychrotrophic bacteria present in cooled raw milk, and AI-2 activity is produced by bacteria associated with the smear of surface-ripened cheeses (Pinto et al., 2007; Gori et al., 2011). Interestingly, AI-2 activity was detected in regular and organic milk even though the bacterial populations were lower than $2 \log \mathrm{cfu} / \mathrm{ml}$, but pasteurization and ultra-pasteurization did not completely neutralize the activity, corroborating earlier observations about AI-2 activity, which proved to be acid stable, base labile, and resistant until $80^{\circ} \mathrm{C}$ (with a loss of activity at $100^{\circ} \mathrm{C}$; Surette and Bassler, 1998; Lu et al., 2004). Moreover, the analyses of cell-free samples revealed the presence of AHLs in raw milk as well as in pasteurized and UHT-treated milk (Ammor et al., 2008).

\section{BIOFILMS IN DAIRIES}

\section{Generalities}

Considering the high availability of nutrients, biofilms (BFs) are very widespread in both the food and beverage industries. In dairies, aside from some rare exceptions (Lortal et al., 2009; Bassi et al., 2017), BFs are mostly associated with continuous hygiene problems and serious economic losses (Carpentier and Cerf, 1993; Sharma and Anand, 2002; Marchand et al., 2012). Surface contamination of food processing lines plays a major role in food contamination; therefore, strict regulations regarding materials in contact with food are applied. Similarly, storage, transportation, and processing of raw milk from farms to dairies occur in storage and process tanks and tubes through which milk circulates, which are mostly made of stainless steel, widely favored for its neutrality, easiness to clean, thermal conductivity, and resistance to harsh detergents; however, some smaller pieces such as seals and gaskets are made of rubber (Tetra Pak, 2003). The rich composition of milk directly provides components that contribute to BF development (Figure 1); bacterial activities furnish other crucial compounds such as exopolysaccharides (EPS), teichoic acids, and extracellular DNA (eDNA; Gross et al., 2001; Sutherland, 2001; Schwartz et al., 2016).

Most if not all gram-positive bacteria, including spore formers, and gram-negative bacteria present in raw milk have the ability to form BFs; both spores and vegetative cells can attach to stainless steel and fouled surfaces; in addition, sporulation occurs within BFs (Wijman et al., 2007; Marchand et al., 2012; Faille et al., 2014).

Consequently, multi-generic or multispecies BFs can be found in dairies (Marchand et al., 2012). In dairy manufacturing plants, two types of BFs are distinguished: environmental BFs, which form in the processing environment (in places difficult to clean) and process BFs, which are established on process line surfaces in contact with the flowing product or on ultrafiltration and reverse osmosis membranes, as well as on vulnerable parts such as T-junctions or "dead legs" prone to fouling; process line
BFs are characterized by rapid growth (within hours) whereas environmental BFs usually grow slower; mostly, in BFs associated with process equipment, one or a few species dominate, in contrast to environmental BFs, which are characterized by higher bacterial diversity (Carpentier and Cerf, 1993; Chambers, 2002; Bremer et al., 2015).

\section{Some Physicochemical Factors That Affect Biofilms in Dairies}

The diversity and remarkable adaptability features of bacteria and spores present in raw milk allow them to thrive at any temperature in dairies; this point is illustrated by the ability of these organisms to grow at even higher temperatures in BFs than the usual growth temperature for the planktonic state (Teh et al., 2012). Unsurprisingly, some particular traits of psychrotrophs such as the capacity to produce higher yields of enzymes and polysaccharides at low temperatures allow psychrotrophic bacteria to dominate in BFs established during cold storage (Jay et al., 2006). On the other hand, the obligate thermophilic spore formers such as Geobacillus sp. and Anoxybacillus sp., most prevalent in dairy powders, will become established on processing lines where temperatures between 40 and $65^{\circ} \mathrm{C}$ support their growth as well as $\mathrm{BF}$ formation; the simultaneous mesophilic and thermophilic features of Bacillus licheniformis, another spore former also commonly isolated in dairy powders, make it a major dairy continuum contaminant (Zhao et al., 2013; Flint et al., 2015; Kent et al., 2016). Their persistence in BFs is largely due to the overcoming of the selective pressures in the dairy manufacturing plant, as these bacterial types have perfectly adapted to heat, $\mathrm{pH}$, water availability, and specific product composition (Burgess et al., 2010).

The $\mathrm{pH}$ values from fresh unspoiled raw milk range from 6.6 to 6.8 at $20^{\circ} \mathrm{C}$, but prolonged cold storage promotes a decrease in raw milk $\mathrm{pH}$; several reports have shown that lower $\mathrm{pH}$ values favor BF formation (Skura et al., 1986; Dechemi et al., 2005; Dat et al., 2012; Atulya et al., 2014; Miranda et al., 2018; Munsch-Alatossava et al., 2019).

Milk is continuously exposed to air (with an oxygen content of $21 \%$ ) at the milking, handling, and transportation stages from farms to dairies. The presence of $\mathrm{O}_{2}$ is associated with two drawbacks: the problem of maintaining the quality of milk as the auto-oxidation process deteriorates the flavors and nutritional properties of raw milk and dairy products (Walstra et al., 2006) and the resulting bacterial development as psychrotrophs are also favored by aeration (Jay et al., 2006). The impact of aeration on the generation time of Pseudomonas fluorescens, a common inhabitant of raw milk, when examined within a temperature range of 4 to $32^{\circ} \mathrm{C}$ revealed that the greatest effect of aeration occurred at 4 and $10^{\circ} \mathrm{C}$ (Olsen and Jezeski, 1963). As shown for other BF types, bacteria cope remarkably well with variable oxygen/air concentrations within dairy BFs: as observed for P. fluorescens (Spiers et al., 2003) or B. cereus (Wijman et al., 2007), the thermophilic spore formers Anoxybacillus and Geobacillus also preferentially established BFs at air-liquid interfaces rather than on submerged surfaces (Zhao et al., 2013).

In the dairy, as for other environments, the physicochemical features of the material surface greatly determine the efficiency of 
bacterial attachment and BF formation. Several reports indicate that the charge and hydrophobicity of the surface constitute the major components that influence bacteria-surface interactions; moreover, the surface roughness or its topographic configuration may also contribute to bacterial attachment and BF formation (Palmer et al., 2015; Berne et al., 2018; Achinas et al., 2019).

\section{Native Milk Components That Contribute to Biofilm Establishment}

The influence of individual milk components on BFs was highlighted by the observations that lactose and non-casein protein solutions yielded the greatest numbers of cells attached on surfaces, whereas skim milk reduced the attachment of Staphylococcus aureus, Serratia marcescens, and L. monocytogenes on stainless steel; moreover, $\mathrm{BF}$ formation by $B$. cereus isolates was impaired by a ten-fold dilution of whole milk, and $\alpha$-and $\beta$-caseins were described as the primary inducers of BF growth for Streptococcus uberis (Speers and Gilmour, 1985; Barnes et al., 1999; Shaheen et al., 2010; Varhimo et al., 2011). Sequential changes that lead to conditioning of the stainless steel surface, allowing the formation of a multilayer, include the adsorption of $\beta$-lactoglobulin (the major whey protein) at neutral $\mathrm{pH}$ on the negatively charged surface; in the following, $\kappa$-casein protein adsorbs on the previous layer (this step is favored by a temperature increase; Kim and Lund, 2007; Bassi et al., 2017).

Lactose, the major carbohydrate in milk, has also been reported to trigger BF formation by Streptococcus mutans and induce the formation of BF bundles and colony-type BFs for Bacillus subtilis (Assaf et al., 2015; Duanis-Assaf et al., 2016).

Divalent cations can influence BF formation directly by reinforcing the cohesiveness of the structure when $\mathrm{Ca}^{2+}$ cations bond polymer molecules (Turakhia and Characklis, 1989; Carpentier and Cerf, 1993) or indirectly when $\mathrm{Ca}^{2+}$ and $\mathrm{Mg}^{2+}$ affect bacterial attachment (Flint et al., 2015).

\section{Biofilm Formation Favored by the Degradation of Native Milk Components and by the Presence of Secondary Metabolites}

Importantly, BF formation in dairies is also promoted by different products resulting from the different hydrolysis reactions that target various milk components. For example, the extracellular proteolytic activity of $S$. uberis is suggested to contribute to increased BF formation (Varhimo et al., 2011). However, regarding proteinases/proteases, bacterial-associated proteolytic activities impact BFs differently. Various lactic acid bacteria produce cell wall-bound proteinases; for lactococcal cells, the proteinase PrtP exhibits a double function, as in addition to its role in milk casein degradation it confers bacterial cells greater hydrophobicity and adhesion to solid surfaces (El Soda et al., 1986; Habimana et al., 2007). A recent report highlighted a similar role for the proteinase PrtS that mediates BF formation by one Streptococcus strain (Bassi et al., 2017). However, extracellular protease activity is also required for Staphylococcus aureus BF dispersal (Boles and Horswill, 2008). Interestingly, two functions were also assigned to $\mathrm{RbmA}$, a matrix protein that surrounds
Vibrio cholerae cells; apart from contributing to a reinforcement of the BF structure, the in situ limited proteolysis of RbmA promoted the recruitment of planktonic cells (which had not initiated VPS polysaccharide synthesis at the time; Smith et al., 2015).

Interestingly, one study showed that butyric acid, released during lipolysis or milk fat hydrolysis, induced the formation of BF bundles in several Bacillus species (such as B. cereus, B. subtilis and B. licheniformis; Pasvolsky et al., 2014).

Several studies reported that bacteria alter their membranelipid composition when entering a biofilm lifestyle by incorporating free exogenous FAs from the host or from the environment (Giles et al., 2011; Hobby et al., 2019); additionally, Pseudomonas aeruginosa responds to exogenous polyunsaturated fatty acids (PUFAs) by modifying its phospholipid membrane composition and phenotypes associated with virulence including $\mathrm{BF}$ formation, which was enhanced by several PUFAs (Baker et al., 2018).

Pseudomonas aeruginosa, also a causative agent of bovine mastitis, has been isolated from raw milk (Dogan and Boor, 2003; Bannerman et al., 2005; Munsch-Alatossava and Alatossava, 2006). Both in raw milk or in post-pasteurization contamination situations, bacterial phospho/lipolytic activities at planktonic or sessile stages provide fatty acids including oleic acid, the principal unsaturated fatty acid in milk (Figure 1). Interestingly, it was shown that $P$. aeruginosa contains a fatty-acid diol synthase that catalyzes the stereospecific oxygenation of exogenous oleic acid; the production and sensing of oleic acid-derived "oxylipins" regulate $\mathrm{BF}$ formation, and oxylipins are at the basis of a novel quorum sensing system (ODS) believed to be more widely distributed among bacterial species (Martinez and CamposGómez, 2016; Martinez et al., 2019). Notably, a recent study showed that oxylipins detected in bovine milk were mainly composed of linoleic (C18:2) and $\alpha$-linolenic acid (C18:3) metabolites (Goncalves Dias et al., 2020).

Phospholipolysis, caused by various bacterial phospholipases, promoted an increase in the amount of lysophospholipids (LPE, LPC, LPI, and LPS) in raw milk during cold storage (MunschAlatossava et al., 2018a). A link between lysophospholipids and BFs was established for $P$. aeruginosa, as host-derived LPC (lysoPC) modulated the expression of protein RahU involved in the regulation of $\mathrm{BF}$ formation (Rao et al., 2011); for Salmonella, it was shown that the production and secretion of active flagellin (the principal component of flagella) occurred in response to the sensing of host-produced lysophospholipids (Subramanian and Qadri, 2006). Flagella exert a critical role in lifestyle switch during BFs attachment and detachment stages; in the later, $P$. aeruginosa cells synthesized again flagellin before returning to the planktonic state (Suriyanarayanan et al., 2016; Berne et al., 2018).

Both Bacillus and Pseudomonas species, well represented in raw milk, are well known for producing secondary metabolites such as CLPs. Among their various biological roles, CLPs are involved in bacterial surface attachment and BF formation; the type of CLP determines whether the producing bacteria are supported in BF formation such as massetolide A or xantholysin, or whether the CLPs inhibit BF formation (Kuiper et al., 2004; 
De Bruijn et al., 2008; Rokni-Zadeh et al., 2012; Li et al., 2013). Interestingly, the presence of CLPs was evidenced in raw milk and found to "falsify" antibiotic residue detection (Reybroeck et al., 2014).

\section{Repercussions of Dairy Biofilms}

The consequences of dairy-associated BFs are multifaceted: compared to planktonic cells, sessile bacteria show an enhanced production of proteases and lipases (Teh et al., 2012, 2013). BF dispersal inevitably leads to contamination of raw, heat-treated milk, and dairy products, as many enzymes produced at BF stages also show remarkable heat stability and their activities promote off-flavors in end products. The presence of BFs on dairy equipment is also associated with an increased corrosion rate, reduced heat transfer, and increased fluid frictional resistance (Kumar and Anand, 1998; Bremer et al., 2006).

Bovine mastitis, the inflammatory reaction of udder tissue in response to microbial infection, is very difficult to control in dairy farms; the disease has a very high incidence in these farms and causes significant economic losses worldwide (FAO, 2014; Rollin et al., 2015; OECD-FAO, 2019). A significant number of bacterial types can cause mastitis while simultaneously having the ability to form BFs inside the udder (Schönborn and Krömker, 2016). Among the mastitis-associated bacteria (Staphylococcus aureus, Streptococcus spp., E. coli, Salmonella spp., etc.), some are also human pathogens and can be transmitted via milk (Van Asselt et al., 2017), especially if no preliminary heat treatment takes place.

Particular recalcitrant-thermophilic spore former-based BFs necessitate costly precautions such as intensive product controls, frequent cleaning, and shorter production runs (Zhao et al., 2013). Moreover, the use of various detergents and disinfectants, together with insufficient rinsing operations, is associated with the presence of existing and emerging residues in milk and dairy products; for example, residues of iodine and quaternary ammonium compounds have been found in milk, and an excessive level of hydrogen peroxide was recorded in butter (Danaher and Jordan, 2013; Van Asselt et al., 2017).

\section{ANTI-BIOFILM STRATEGIES IN DAIRIES}

In the food industry, the control of the quality and safety of food relies on prevention means such as the strict application of Good Manufacturing Practices (GMP) and Hazard Analysis of Critical Control Points (HACCP; Jay et al., 2006). In dairies, the cleaning (elimination of soiling), and disinfection (destruction of microorganisms) operations of food manufacturing materials typically occur through the "Cleaning-in-Place" (CIP) procedure, which is based on high-velocity passage of hot water and alkaline/acidic detergents, followed by hot water rinsing of the equipment surfaces. Deficiencies in sanitation programs or limitations of CIP regimes (due to the high resistance of spores) inevitably lead to BF formation and extension in dairy plants (Carpentier and Cerf, 1993; Austin and Bergeron, 1995; Sharma and Anand, 2002; Tetra Pak, 2003, Bremer et al., 2006; Faille et al., 2014).
The magnitude of the problems caused by BFs is reflected by the diversity of the investigated anti-BF strategies including the control of milk pH (Dat et al., 2012), the application of a modified CIP regime (with the addition of enzymes, for example; Paul et al., 2014); the use of bacteriophages, phage lysins (Gutierrez et al., 2016), and bacteriocins (with individual or combined use; Cleveland et al., 2001; de Pimentel-Filho et al., 2014); the coating of surfaces with peptides (Friedlander et al., 2019); the application of ultrasonication (Oulahal et al., 2004); the use of ozone (Khadre and Yousef, 2001; Varga and Szigeti, 2016); and the enrichment of milk with at least $5 \mathrm{mM}$ magnesium (Ben-Ishay et al., 2017); however, no effective technological solution exists yet (Friedlander et al., 2019).

\section{$\mathrm{N}_{2}$ GAS FLUSHING TECHNOLOGY}

\section{Major Results With Raw Milk}

To prevent bacterial spoilage of raw milk during cold storage, two studies evaluated the use of $\mathrm{N}_{2}$ gas applied in a "closed system" (Murray et al., 1983; Dechemi et al., 2005). By considering an "open system" somehow more realistic considering dairy equipment, a pure $\mathrm{N}_{2}$ gas flushing-based technology was devised and tested: briefly, sterile-filtered $\mathrm{N}_{2}$ gas is continuously flushed through the headspace of a milk-containing vessel (MunschAlatossava et al., 2010c,b; Alatossava and Munsch-Alatossava, 2018). The method proved to be of interest as an additional or alternative treatment by hindering bacterial development and simultaneously preventing the bio/chemical degradation of raw milk components during cold storage (Table 1).

\section{Studies With Gram-Positive and Gram-Negative Bacterial Representatives}

When the $\mathrm{N}_{2}$ gas flushing treatment was applied to the gram-negative $P$. fluorescens raw milk isolate $\mathrm{C} 1$, its growth was inhibited during the exponential growth phase compared to the control conditions (ambient air) at both considered temperatures $\left(6\right.$ and $12^{\circ} \mathrm{C}$; Munsch-Alatossava and Alatossava, 2006; Munsch-Alatossava et al., 2010c); investigations with the gram-positive spore former Bacillus weihenstephanensis (strain KBAB4) revealed a temperature-dependent behavior: the treatment promoted the emergence of small colony variants (SCVs) at $15^{\circ} \mathrm{C}$, but most importantly, scanning and transmission electron microscopy analyses revealed that the treatment triggered cell death at $25^{\circ} \mathrm{C}$ (Munsch-Alatossava and Alatossava, 2014). Mono- and co-cultures of both C1 and KBAB4 strains in Brain Heart Infusion (BHI) broth showed the presence of BFs (rather diffuse for the co-culture and denser for the monoculture) on the surface of the test bottles used for the cultivation of the controls ( $\mathrm{C}$; conditions 2 and 4, Figure 3A), in contrast, to the bottles that received the additional $\mathrm{N}_{2}$ flushing treatments (N; conditions 1 and 3), for which no such observations were made (Figure 3A). Pseudomonas sp. raw milk isolate J8 (Munsch-Alatossava and Alatossava, 2006), cultured in $\mathrm{BHI}$ broth, showed a similar behavior: development of a BF in the 
TABLE 1 | Summary of the advantages determined with the use of $\mathrm{N}_{2}$ gas.

\begin{tabular}{|c|c|c|}
\hline $\begin{array}{l}\text { Microbiological } \\
\text { aspects }\end{array}$ & Effects & References \\
\hline & $\begin{array}{l}\text { Inhibition of bacterial growth } \\
\text { at low and milder } \\
\text { temperatures at laboratory } \\
\text { scale (culture-based studies) }\end{array}$ & $\begin{array}{l}\text { Murray et al., 1983; Skura } \\
\text { et al., 1986; Dechemi et al., } \\
\text { 2005; Munsch-Alatossava } \\
\text { et al., 2010c, 2016, 2018a }\end{array}$ \\
\hline & $\begin{array}{l}\text { "Exclusion" of phospholipase } \\
\text { producers and vegetative } \\
\text { cells of the Bacillus cereus } \\
\text { type (culture-based studies) } \\
\text { in raw milk }\end{array}$ & $\begin{array}{l}\text { Munsch-Alatossava et al., } \\
\text { 2010c,a }\end{array}$ \\
\hline & $\begin{array}{l}\text { Inhibition of bacterial growth } \\
\text { at pilot plant scale (100 L) }\end{array}$ & $\begin{array}{l}\text { Munsch-Alatossava et al., } \\
\text { 2010b }\end{array}$ \\
\hline & $\begin{array}{l}\text { Better preservation of the } \\
\text { initial bacterial diversity during } \\
\text { raw milk cold storage; } \\
\text { Inhibition of Pseudomonas } \\
\text { and Acinetobacter } \\
\text { (next-generation } \\
\text { sequencing-rRNA-based } \\
\text { study) }\end{array}$ & Gschwendtner et al., 2016 \\
\hline & $\begin{array}{l}\text { Bactericidal against Bacillus } \\
\text { weihenstephanensis }\end{array}$ & $\begin{array}{l}\text { Munsch-Alatossava and } \\
\text { Alatossava, } 2014\end{array}$ \\
\hline & Anaerobes are not favored & $\begin{array}{l}\text { Munsch-Alatossava et al., } \\
\text { 2010c; Gschwendtner } \\
\text { et al., } 2016\end{array}$ \\
\hline & $\begin{array}{l}\text { Similar efficiency as that of } \\
\text { the activated lactoperoxidase } \\
\text { system at milder } \\
\text { temperatures }\end{array}$ & $\begin{array}{l}\text { Munsch-Alatossava et al., } \\
2016\end{array}$ \\
\hline & $\begin{array}{l}\text { Dissemination of antibiotic } \\
\text { resistance is hindered }\end{array}$ & $\begin{array}{l}\text { Munsch-Alatossava et al., } \\
2017\end{array}$ \\
\hline & Sporulation is not promoted & $\begin{array}{l}\text { Munsch-Alatossava et al., } \\
\text { 2013; Munsch-Alatossava } \\
\text { and Alatossava, } 2014\end{array}$ \\
\hline $\begin{array}{l}\text { Biochemical } \\
\text { aspects }\end{array}$ & Prevents or alleviates & References \\
\hline & Proteolysis & $\begin{array}{l}\text { Murray et al., 1983; Skura } \\
\text { et al., 1986; Dechemi et al., } \\
\text { 2005; Munsch-Alatossava } \\
\text { et al., } 2019\end{array}$ \\
\hline & Lipolysis & $\begin{array}{l}\text { Murray et al., 1983; } \\
\text { Dechemi et al., 2005; } \\
\text { Munsch-Alatossava et al., } \\
2019\end{array}$ \\
\hline & Phospholipolysis & $\begin{array}{l}\text { Munsch-Alatossava et al., } \\
2018 \text { a }\end{array}$ \\
\hline & Auto-oxidation & $\begin{array}{l}\text { Gursoy et al., 2017; } \\
\text { Munsch-Alatossava et al., } \\
2019\end{array}$ \\
\hline & Maintains initial raw milk pH & $\begin{array}{l}\text { Murray et al., 1983; } \\
\text { Dechemi et al., 2005; } \\
\text { Munsch-Alatossava et al., } \\
\text { 2010c, } 2019\end{array}$ \\
\hline
\end{tabular}

control conditions (C; ambient air), whereas no BF was apparent when the $\mathrm{N}_{2}$-flushing treatment was applied ( $\mathrm{N}$; Figure $3 \mathrm{~B}$ ). Hypotheses on possible modes of action of $\mathrm{N}_{2}$ flushing on grampositive or gram-negative bacterial types were discussed in a previous report (Munsch-Alatossava et al., 2018b).

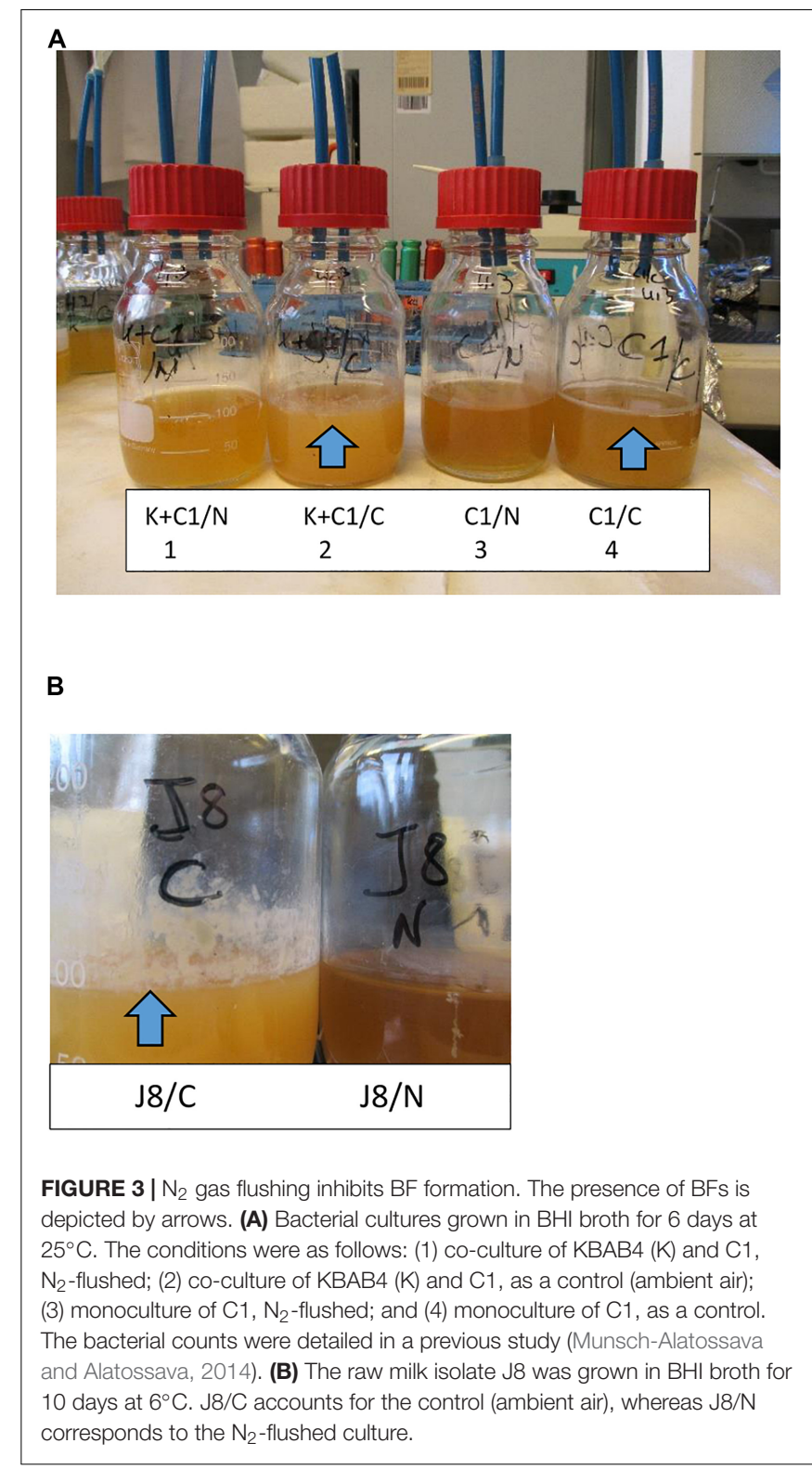

\section{HOW COULD N 2 GAS FLUSHING CONTRIBUTE TO PREVENTING BIOFILM FORMATION?}

All studies that evaluated $\mathrm{N}_{2}$ gas-based treatments in "closed" or "open" systems showed that the treatment overcomes some major drawbacks underlying "cold storage for a certain time," concluding that aerobic and facultative anaerobic vegetative bacterial development was impeded, anaerobes were not favored, and some bacterial groups associated with spoilage were particularly targeted; additionally, the activities of bacterial lipase, protease, phospholipases $\mathrm{C}, \mathrm{A}$, and $\mathrm{D}$, and sphingomyelinase $\mathrm{C}$ were reduced and coincided with little or no bacterial growth in cold-stored $\mathrm{N}_{2}$-flushed raw milk (Table 1). The fact that the $\mathrm{N}_{2}$ treatment better preserves original milk components 


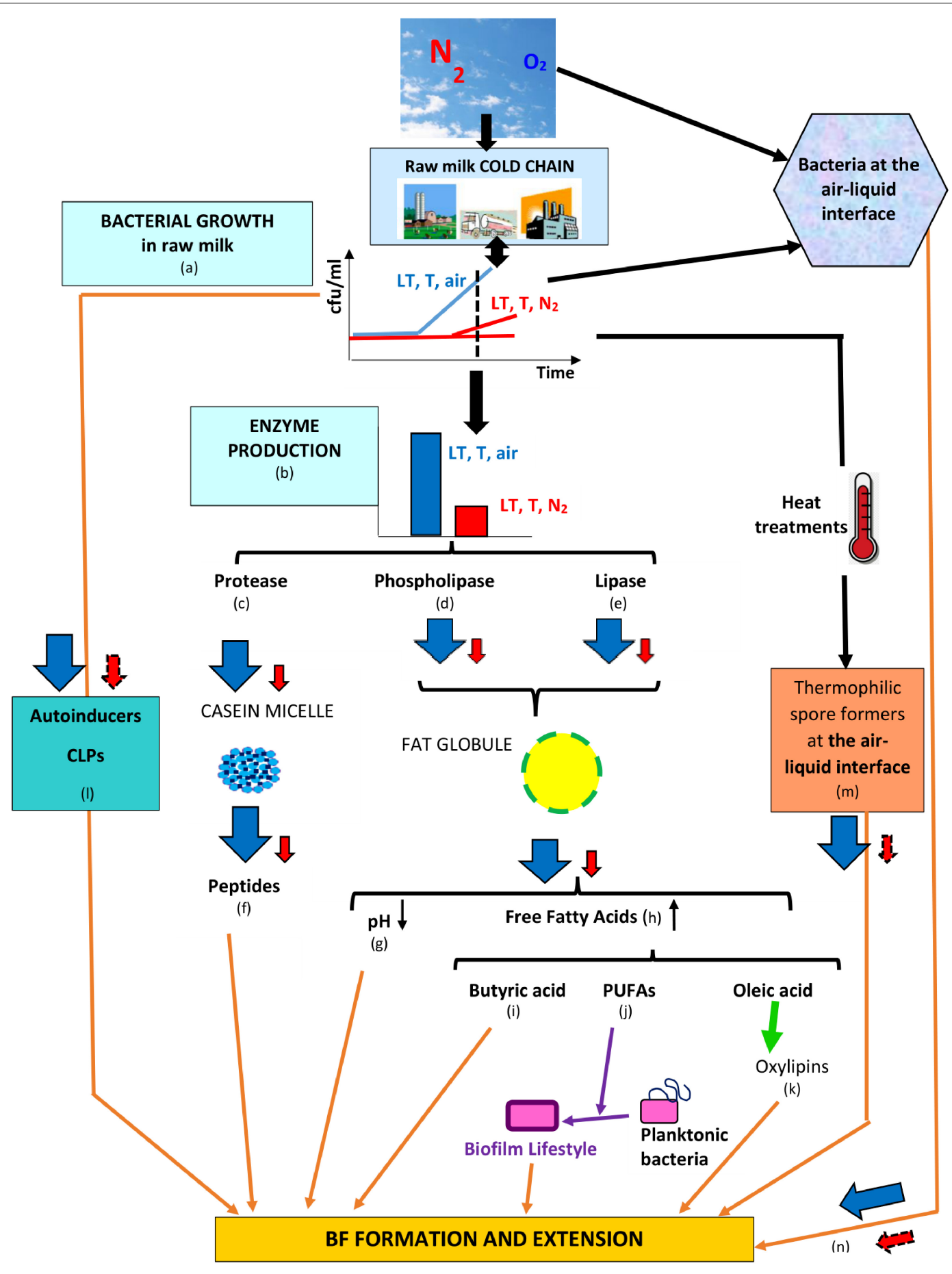

FIGURE 4 | Series of counter-events, triggered by $\mathrm{N}_{2}$ flushing, that could contribute to reducing BF formation in dairies. Legend: LT, $\mathbf{T}$, and air = low temperature for some time at ambient atmosphere $\left(78 \% \mathrm{~N}_{2}, 21 \% \mathrm{O}_{2}\right)$; $\mathbf{L T}, \mathbf{T}$, and $\mathbf{N}_{\mathbf{2}}=$ low temperature for some time under $\mathrm{N}_{2}$ flushing $\left(\sim 100 \% \mathrm{~N}_{2}\right)$; the changes induced by LT, T,

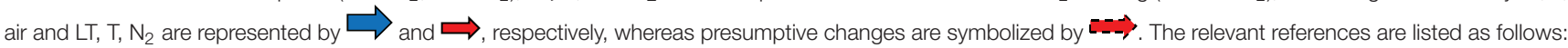
(a) Chambers (2002), Raats et al. (2011), Quigley et al. (2013), Gschwendtner et al. (2016), Dechemi et al. (2005), Munsch-Alatossava et al. (2010c); (b) Murray et al. (1983), Chambers (2002), Dechemi et al. (2005), Munsch-Alatossava et al. (2010c, 2018a, 2019), Vithanage et al. (2016); (c) Murray et al. (1983), Skura et al. (1986), Dechemi et al. (2005), Munsch-Alatossava et al. (2010c, 2019); (d) Munsch-Alatossava et al. (2018a); (e) Dechemi et al. (2005), Munsch-Alatossava et al. (2010c, 2019); (f) El Soda et al. (1986), Habimana et al. (2007), Varhimo et al. (2011), Bassi et al. (2017); (g) Skura et al. (1986), Deeth (2002), Dechemi et al. (2005), Walstra et al. (2006), Dat et al. (2012), Atulya et al. (2014), Munsch-Alatossava et al. (2010c, 2019); (h) Deeth (2002), Taylor and Mac Gibbon (2002), Walstra et al. (2006), Dechemi et al. (2005), Munsch-Alatossava et al. (2019); (i) Pasvolsky et al. (2014); (j) Giles et al. (2011), Baker et al. (2018), Hobby et al. (2019); (k) Martinez and Campos-Gómez (2016), Martinez et al. (2019); (I) Reybroeck et al. (2014), Lu et al. (2004), Ammor et al. (2008); (m) Zhao et al. (2013); and (n) Wijman et al. (2007), Spiers et al. (2003). 
implies that lower amounts of bacterial primary metabolites are released in raw milk (Figure 4); if the flushing treatment would be applied from farms to dairies, a fair assumption would be that raw milk with lower bacterial loads would enter dairies. Moreover, lower bacterial loads imply that lower amounts of EPS would be available and that less eDNA and lower amounts of secondary metabolites such as toxins, CLPs, and autoinducers would be released in raw milk, which could altogether contribute to hindering BF establishment or extension in dairies (Figure 4); presumably, lower levels of autoinducers in $\mathrm{N}_{2}$-flushed raw milk would not benefit eventual post-pasteurization contaminants.

Pure $\mathrm{N}_{2}$ gas flushing prohibited sporulation for B. weihenstephanensis, irrespective on whether the strain was grown in mono- or co-cultures (Munsch-Alatossava and Alatossava, 2014). Furthermore, total spore levels in raw and pasteurized milk did not increase, compared to their initial levels, with the flushing treatment (Munsch-Alatossava et al., 2013, 2018a). Similar observations with oxygen-limited conditions were reported: for Bacillus stearothermophilus, the sparging of cultures with nitrogen instead of air inhibited spore formation (Long and Williams, 1960); similarly, in oxygenlimited conditions, sporulation of one Bacillus thuringiensis strain was reduced (Avignone-Rossa et al., 1992).

The heat stability of certain compounds such as autoinducers (for example AI-2; Surette and Bassler, 1998; Lu et al., 2004; Ammor et al., 2008) and CLPs (Reybroeck et al., 2014), present in food materials including dairy products, raises questions about their outcomes and eventual interactions with the gut microbiota. Interestingly, a recent study showed that mammalian epithelial cells produce a mimic of the bacterial autoinducer AI-2 in response to secreted bacterial factors; the authors also suggest that cross-kingdom communication occurs between eukaryotic cells and bacteria via the AI-2 bacterial quorum sensing system (Ismail et al., 2016).

By creating conditions that lower the availability of free oleic acid (Figure 4), $\mathrm{N}_{2}$ flushing could also disturb the oxylipin-based QS circuitry and hence contribute to limiting BF formation or extension by bacterial types that rely on ODS (Martinez et al., 2019; Figure 4).

Considering limitations underlying the recommended raw milk preservation methods (FAO, 2005; Munsch-Alatossava and Alatossava, 2007; Munsch-Alatossava et al., 2012; Teh et al., 2012; Botelho et al., 2015) together with problems caused by BFs in dairies (Carpentier and Cerf, 1993; Sharma and Anand, 2002; Marchand et al., 2012), future actions that aim to ensure microbial food safety will inevitably imply considering climate change and more precisely how to maintain the cold chain of raw milk storage and transportation when ambient temperatures are rising. Technological solutions that could prevent or hinder BF formation in dairies would result in less spoilage, fewer outbreaks,

\section{REFERENCES}

Achinas, S., Charalampogiannis, N., and Euverink, G. J. W. (2019). A brief recap of microbial adhesion and biofilms. Appl. Sci. 9:2801. doi: 10.3390/app9142801 and use of less water and detergents, which could ultimately benefit dairy farms, industries, and consumers.

That the $\mathrm{N}_{2}$ flushing treatment could exhibit anti-biofilm properties is somewhat directly suggested from the observation of mono- and co-cultures of bacterial strains (Figure 3); however, further studies are necessary to precisely evaluate and quantify anti-BF properties of a pure $\mathrm{N}_{2}$-based atmosphere.

\section{CONCLUSION}

Future actions that ameliorate food waste and losses, while ensuring microbial food safety, must address sustainable development goals established by the United Nations (Sustainable Development Goals, 2015) in a context where higher ambient temperatures will inevitably impose increasing pressure on maintaining the cold chain of food storage and transportation.

Strategies that aim to achieve better control of BFs are divided in either preventing BF formation or targeting mature BFs. In dairies, as elsewhere, the formation of BFs is conditioned by the balance between favorable and antagonistic factors; by reducing the beneficial effects exerted by favorable factors of either a microbiological or biochemical type, $\mathrm{N}_{2}$ gas flushing could contribute to preventing or limiting $\mathrm{BF}$ formation and extension.

\section{AUTHOR CONTRIBUTIONS}

PM-A wrote the 1st draft of the manuscript. TA contributed to data compilation related to biochemical and dairy technological aspects and critically read and commented the manuscript. Both authors contributed to the article and approved the submitted version.

\section{ACKNOWLEDGMENTS}

The authors gratefully acknowledge MSc Eng. Dominique Ibarra and Dr. Youbi-Idrissi Mohammed for their valuable contributions to the studies related to the hydrolysis of milk components; these studies were supported by a specific research grant from $M$. Leprince-Ringuet (Director of the Paris Saclay Research Centre of Air Liquide, France). The authors also express deep gratitude to Pr. Michael Schloter (Helmholtz Zentrum München, Germany) and to his team for the precious collaborative work concerning the NGS studies and to Dr. Reijo Käkelä (University of Helsinki) for the raw milk-lipidomics investigations. They also thank MSc Eng./CEO Antti Alavuotunki (Helsingin Meijeriliike Ltd., Helsinki, Finland) for the gift of all raw milk samples.

Alatossava, T., and Munsch-Alatossava, P. (2018). European Patent 2162021. Munich: European Patent Office.

Ammor, M. S., Michaelidis, C., and Nychas, G.-J. E. (2008). Insights into the role of quorum sensing in food spoilage. J. Food Protect. 71, 1510-1525. doi: $10.4315 / 0362-028 x-71.7 .1510$ 
Assaf, D., Steinberg, D., and Shemesh, M. (2015). Lactose triggers biofilm formation by Streptococcus mutans. Int. Dairy J. 42, 51-57. doi: 10.1016/j. idairyj.2014.10.008

Atulya, M., Jesil Mathew, A., Venkata Rao, J., and Mallikarjuna Rao, C. (2014). Influence of milk components in establishing biofilm mediated bacterial mastitis infections in cattle: a fractional factorial approach. Res. Vet. Sci. 96, 25-27. doi: 10.1016/j.rvsc2013.12.001

Augère-Granier, M. L. (2018). The EU dairy sector- European Parliamentary Research Service (PE 630345, December 2018). Brussels: European Parliament.

Austin, J. W., and Bergeron, G. (1995). Development of bacterial biofilms in dairy processing lines. J. Dairy Res. 62, 509-519. doi: 10.1017/s0022029900031204

Avignone-Rossa, C., Arcas, J., and Mignone, C. (1992). Bacillus thuringiensis growth, sporulation and $\delta$-endotoxin production in oxygen limited and nonlimited cultures. World J. Microbiol. Biotechnol. 8, 301-304. doi: 10.1007/ BF01201884

Baker, L. Y., Hobby, C. R., Siv, A. W., Bible, W. C., Glennon, M. S., Anderson, D. M., et al. (2018). Pseudomonas aeruginosa responds to exogenous polyunsaturated fatty acids (PUFAs) by modifying phospholipid composition, membrane permeability, and phenotypes associated with virulence. BMC Microbiol. 18:117. doi: 10.1186/s12866-018-1259-8

Bannerman, D. D., Chockalingam, A., Paape, M. J., and Hope, J. C. (2005). The bovine innate immune response during experimentally-induced Pseudomonas aeruginosa mastitis. Vet. Immun. Immunopath. 107, 201-215. doi: 10.1016/j. vetimm.2005.04.012

Barnes, L. M., Lo, M. F., Adams, M. R., and Chamberlain, A. H. L. (1999). Effect of milk proteins on adhesion of bacteria to stainless steel surfaces. Appl. Environ. Microbiol. 65, 4543-4548. doi: 10.1128/aem.65.10.4543-4548.1999

Bassi, D., Cappa, F., Gazzola, S., Orrù, L., and Cocconcelli, P. S. (2017). Biofilm formation on stainless steel by Streptococcus thermophilus UC8547 in milk environments is mediated by the proteinase PrtS. Appl. Environ. Microbiol. 83, 1-12. doi: 10.1128/AEM.02840-16

Ben-Ishay, N., Oknin, H., Steinberg, D., Berkovich, Z., Reifen, R., and Shemesh, M. (2017). Enrichment of milk with magnesium provides healthier and safer dairy products. NPJ Biofilms Microbiomes 3:24. doi: 10.1038/s41522-017-0032-3

Berne, C., Ellison, C. K., Ducret, A., and Brun, Y. V. (2018). Bacterial adhesion at the single-cell level. Nat. Rev. Microbiol. 16, 617-627. doi: 10.1038/s41579-0180057-5

Boles, B. R., and Horswill, A. R. (2008). agr- mediated dispersal of Staphylococcus aureus biofilms. PLoS Pathog. 4:e1000052. doi: 10.1371/journal.ppat.1000052

Botelho, B., Reis, N., Oliveira, L. S., and Sena, M. M. (2015). Development and analytical validation of a screening method for simultaneous detection of five adulterants in raw milk using mid-infrared spectroscopy and PLS-DA. Food Chem. 181, 31-37. doi: 10.1016/j.foodchem.2015.02.077

Bremer, P., Flint, S., Brooks, J., and Palmer, J. (2015). "Introduction to biofilms: definition and basic concepts," in Biofilms in the dairy industry, eds K. H. Teh, S. Flint, J. Brooks, and G. Knight (Hoboken, NJ: Wiley), 1-16. doi: 10.1002/ 9781118876282.ch1

Bremer, P. J., Fillery, S., and McQuillan, A. J. (2006). Laboratory scale CleanIn-Place (CIP) studies on the effectiveness of different caustic and acid wash steps on the removal of dairy biofilms. Int. J. Food Microbiol. 106, 254-262. doi: 10.1016/j.ijfoodmicro.2005.07.004

Burgess, S. A., Lindsay, D., and Flint, S. H. (2010). Thermophilic bacilli and their importance in dairy processing. Int. J. Food Microbiol. 144, 215-225. doi: $10.1016 /$ j.ijfoodmicro.2010.09.027

Carpentier, B., and Cerf, O. (1993). Biofilms and their consequences, with particular reference to hygiene in the food industry. J. Appl. Bacteriol. 75, 499-511. doi: 10.1111/j.1365-2672.1993-tb01587x

Centers for Disease Control and Prevention (2017). Available online at: https: //www.cdc.gov/foodsafety/rawmilk/raw-milk-resources.html (accessed March 3, 2020).

Chambers, J. V. (2002). "The microbiology of raw milk," in Dairy Microbiology Handbook, ed. R. K. Robinson (New York, NY: Wiley), 39-89.

Chrisope, G. L., and Marshall, R. T. (1976). Combined action of lipase and microbial phospholipase $\mathrm{C}$ on a model fat globule emulsion and raw milk. J. Dairy Sci. 59, 2024-2030. doi: 10.3168/jds.s0022-0302(76)84483-9

Christensen, A. B., Riedel, K., Eberl, L., Flodgaard, L. R., Molin, S., Gram, L., et al. (2003). Quorum-sensing-directed protein expression in Serratia proteamaculans B5a. Microbiology 149, 471-483. doi: 10.1099/mic.0.25575-0
Clay, N., Garnett, T., and Lorimer, J. (2020). Dairy intensification: drivers, impacts and alternatives. Ambio 49, 35-48. doi: 10.1007/s13280-019-01177-y

Cleveland, J., Montville, T. J., Nes, I. F., and Chikindas, M. L. (2001). Bacteriocins: safe natural antimicrobials for food preservation. Int. J. Food Microbiol. 71, 1-20. doi: 10.1016/s0168-1605(01)00560-8

Cousin, M. A. (1982). Presence and activity of psychrotrophic microorganisms in milk and dairy products: a review. J. Food Prot. 45, 172-207. doi: 10.4315/0362028X-45.2.172

Danaher, M., and Jordan, K. (2013). Identification of existing and emerging chemical residue contamination concerns in milk. Irish J. Agric. Food Res. 52, 173-183.

Dat, N. M., Hamanaka, D., Tanaka, F., and Uchino, T. (2012). Control of milk pH reduces biofilm formation of Bacillus licheniformis and Lactobacillus paracasei on stainless steel. Food Control 23, 215-220. doi: 10.1016/j.foodcont.2011. 07.013

Davies, D. G., Parsek, M. P., Pearson, J. P., Iglewski, B. H., Costerton, J. W., and Greenberg, E. P. (1998). The involvement of cell-to-cell signals in the development of a bacterial biofilm. Science 280, 295-298. doi: 10.1126/science. 280.5361.295

De Bruijn, I., De Kock, M. J. D., De Waard, P., Van Beek, T. A., and Raaijmakers, T. A. (2008). Massetolide A biosynthesis in Pseudomonas fluorescens. J. Bacteriol. 190, 2777-2789. doi: 10.1128/JB.01563-07

de Pimentel-Filho, N., de, J., De Freitas Martins, M. C., Nogueira, G. B., Mantovani, H. C., and Dantas Vanetti, M. C. (2014). Bovicin HC5 and nisin reduce Staphylococcus aureus adhesion to polystyrene and change the hydrophobicity profile and Gibbs free energy of adhesion. Int. J. Food Microbiol. 190, 1-8. doi: 10.1016/j.ijfoodmicro.2014.08.004

Dechemi, S., Benjelloun, H., and Lebeault, J. M. (2005). Effect of modified atmospheres on the growth and extracellular enzymes of psychrotrophs in raw milk. Eng. Life Sci. 5, 350-356. doi: 10.1002/elsc.200520082

Deeth, H. C. (2002). "Lipolysis," in Encyclopedia of Dairy Sciences, eds H. Roginski, J. W. Fuquay, and P. F. Fox (London: Academic Press), 1595-1601.

Dogan, B., and Boor, K. J. (2003). Genetic diversity and spoilage potentials among Pseudomonas spp. isolated from fluid milk products and dairy processing plants. Appl. Environ. Sci. 69, 130-138. doi: 10.1128/AEM.69.1.130-138. 2003

Duanis-Assaf, D., Steinberg, D., Chai, Y., and Shemesh, M. (2016). The luxS based quorum sensing governs lactose induced biofilm formation by Bacillus subtilis. Front. Microbiol. 6:1517. doi: 10.3389/fmicb.2015.01517

EFSA (2015). Scientific Opinion on the Public Health Risks Related to the Consumption of Raw Milk, European Food Safety Authority. Available online at: https://www.efsa.europa.eu/en/efsajournal/pub/3940 (accessed March 4, 2020).

El Soda, M., Desmazeaud, M. J., Le Bars, D., and Zevaco, C. (1986). Cellwall-associated proteinases in Lactobacillus casei and Lactobacillus plantarum. J. Food Prot. 49, 361-365. doi: 10.4315/0362-028X-49.5.361

European Parliament Directive (2013). 98/9/ECAnnex III, Section XI. Available online at: https://eur-lex.europe.eu/legal-content/EN, Document020004R085320171121 (accessed March 8, 2020).

Faille, C., Bénézech, T., Midelet-Bourdin, G., Lequette, Y., Clarisse, M., Ronse, G., et al. (2014). Sporulation of Bacillus spp. within biofilms: a potential source of contamination in food processing environments. Food Microbiol. 40, 64-74. doi: 10.1016/j.fm.2013.12.004

FAO (2005). Food and Agriculture Organisation of the United Nations. Benefits and Potential Risks of the Lactoperoxidase System of Raw Milk Preservation. Rome: FAO.

FAO (2014). Food and Agriculture Organisation of the United Nations. Impact of Mastitis in Small Scale Dairy Production Systems. Animal Production and Health Working Paper No13. Rome: FAO.

FAO (2015). Food and Agriculture Organisation of the United Nations. Food Loss and Waste. Rome: FAO.

FAO (2019). Food and Agriculture Organisation of the United Nations. Dairy Market Review: Overview of Global Dairy Market Developments in 2018. Rome: FAO.

Flint, S., Jamaludin, N. M., Somerton, B., Palmer, J., and Brooks, J. (2015). “The effect of milk composition on the development of biofilms," in Biofilms in the Dairy Industry, eds K. H. Teh, S. Flint, G. Knight, and J. Brooks (Hoboken, NJ: John Wiley and Sons), 36-48. doi: 10.1002/9781118876282.ch3

Fox, P. F. (2003). "Significance of indigenous enzymes in milk and dairy products," in Handbook of Food Enzymology, eds J. R. Whitaker, A. G. J. Voragen, and D. W. S. Wong (New York: Marcel Dekker), 255-277. 
Friedlander, A., Nir, S., Reches, M., and Shemesh, M. (2019). Preventing biofilm formation by dairy-associated bacteria using peptide-coated surfaces. Front. Microbiol. 10:1405. doi: 10.3389/fmicb.2019.01405

Gallier, S., Gragson, D., Cabral, C., Jimenez-Flores, R., and Everett, D. (2010). Composition and fatty-acid distribution of bovine milk phospholipids from processed milk products. J. Agric. Food Chem. 58, 10503-10511. doi: 10.1021/ jf101878d

Giles, D. K., Hankins, J. V., Guan, Z., and Trent, S. (2011). Remodelling of the Vibrio cholerae membrane by incorporation of exogenous fatty acids from host and aquatic environments. Mol. Microbiol. 79, 716-728. doi: 10.1111/j.13652958.2010.07476.x

Goncalves Dias, F. F., Augusto-Obara, T. R., Hennebelle, M., Chantieng, S., Ozturk, G., Taha, A. Y., et al. (2020). Effects of industrial heat treatments on bovine milk oxylipins and conventional markers of lipid oxydation. Prost. Leuk. Ess. Fatty Acids 152, 1-7. doi: 10.1016/j.plefa.2019.102040

Gori, K., Moslehi-Jenabian, S., Purrotti, M., and Jespersen, L. (2011). Autoinducer2 activity produced by bacteria found in smear of surface ripened cheeses. Int Dairy J. 21, 48-53. doi: 10.1016/j.idairyj.2010.06.009

Gross, M., Cramton, S. E., Götz, F., and Peschel, A. (2001). Key role of teichoic acid net charge in Staphylococcus aureus colonization of artificial surfaces. Infect. Immun. 69, 3423-3426. doi: 10.1128/IAI.69.5.3423-3426.2001

Gschwendtner, S., Alatossava, T., Kublik, S., Mrkonjic Fuka, M., Schloter, M., and Munsch-Alatossava, P. (2016). N2 gas flushing alleviates the loss of bacterial diversity and inhibits psychrotrophic Pseudomonas during the cold storage of bovine raw milk. PLoS One 11:e0146015. doi: 10.1371/journalpone.0146015

Gursoy, O., Munsch-Alatossava, P., Ertan, K., Yilmaz, Y., and Alatossava, T. (2017). Effect of nitrogen gas flushing treatments on total antioxidant capacity and ascorbic acid content in raw bovine milk during cold storage. Mljekarstvo 67, 155-164. doi: 10.15567/mljekarstvo.2017.0208

Gutierrez, D., Rodriguez-Rubio, L., Martinez, B., Rodriguez, A., and Garcia, P. (2016). Bacteriophages as weapons against bacterial biofilms in the food industry. Front. Microbiol. 7:825. doi: 10.3389/fmicb.2016.00825

Habimana, O., Le Goff, C., Juillard, V., Bellon-Fontaine, M.-N., Buist, G., Kulakauskas, S., et al. (2007). Positive role of cell wall anchored proteinase PrtP in adhesion of lactococci. BMC Microbiol. 7:36. doi: 10.1186/1471-2180-7-36

Hobby, C. R., Herndon, J. L., Morrow, C. A., Peters, R. E., Symes, S. J. K., and Giles, D. K. (2019). Exogenous fatty acids alter phospholipid composition, membrane permeability, capacity for biofilm formation, and antimicrobial peptide susceptibility in Klebsiella pneumoniae. Microbiol. Open 8:e00635. doi: $10.1002 / \mathrm{mbo} .635$

Ismail, A. S., Valastyan, J. S., and Bassler, B. L. (2016). A host-produced autoinducer-2 mimic activates bacterial quorum sensing. Cell Host Microbe 19, 470-480. doi: 10.1016/j.chom.2016.02.020

Ivy, R. A., Ranieri, M. L., Martin, N. H., Den Bakker, H. C., Xavier, B. M., Wiedmann, M., et al. (2012). Identification and characterization of psychrotolerant sporeformers associated with fluid milk production and processing. Appl. Environ. Microbiol. 78, 1853-1864. doi: 10.1128/AEM.065 36-11

Jay, J., Loessner, M. J., and Golden, D. A. (2006). "Protection of foods with low-temperatures," in Modern Food Microbiology, 7th Edn (Cham: Springer), 395-413. doi: 10.1007/0-387-23413-6_16

Kable, M. E., Srisengfa, Y., Laird, M., Zaragoza, J., McLeod, J., Heidenreich, J., et al. (2016). The core and seasonal microbiota of raw bovine milk in tanker trucks and the impact of transfer to a milk processing facility. mBio 7:e00836-16. doi: 10.1128/mBio.00836-16

Keenan, T. W., and Mather, I. H. (2002). "Milk fat globule membrane," in Encyclopedia of Dairy Sciences, eds H. Roginski, J. W. Fuquay, and P. F. Fox (London: Academic Press), 1568-1576. doi: 10.1016/b0-12-227235-8/00263-7

Kent, D. J., Chauhan, K., Boor, K., Wiedmann, M., and Martin, N. H. (2016). Spore test parameters matter: mesophilic and thermophilic spore counts detected in raw milk and dairy powders differ significantly by test method. J. Dairy Sci. 99, 5180-5191. doi: $10.3168 /$ jds.2015.10283

Khadre, M. A., and Yousef, A. E. (2001). Sporicidal action of ozone and hydrogen peroxide: a comparative study. Int. J. Food Microbiol. 71, 131-138. doi: 10.1016/ s0168-1605(01)00561-x

Kim, J. C., and Lund, D. B. (2007). Milk protein/stainless steel interaction relevant to the initial stage of fouling in thermal processing. J. Food Process. Eng. 21, 369-386. doi: 10.1111/j.1745-4530.1998.tb00459x
Kuiper, I., Lagendijk, E. L., Pickford, R., Derrick, J. P., Lamers, G. E. M., Thomas-Oates, J. E., et al. (2004). Characterization of two Pseudomonas putida lipopeptide biosurfactants, putisolvin I and II, which inhibit biofilm formation and break down existing biofilms. Mol. Microbiol. 51, 97-113. doi: 10.1046/j. 1365-2958.2003.03751.x

Kumar, C. G., and Anand, S. (1998). Significance of microbial biofilms in food industry: a review. Int. J. Food Microbiol. 42, 9-27. doi: 10.1016/s0168-1605(98) 00060-9

Li, W., Rokni-Zadeh, H., De Vleeschouwer, M., Ghequire, M. G. K., Sinnaeve, D., Xie, G. L., et al. (2013). The antimicrobial compound xantholysin defines a new group of Pseudomonas cyclic lipopeptides. PLoS One 8:e62946. doi: 10.1371/ journal.pone.0062946

Long, S. K., and Williams, O. B. (1960). Factors affecting growth and spore formation of Bacillus stearothermophilus. J. Bacteriol. 79, 625-628. doi: 10.1128/ jb.79.5.625-628.1960

Lortal, S., Di Blasi, A., Madec, M.-N., Pediliggieri, C., Tuminello, L., Tanguy, G., et al. (2009). Tina wooden vat biofilm: a safe and highly efficient lactic acid bacteria delivering system in PDO Ragusano cheese making. Int. J. Food Microbiol. 132, 1-8. doi: 10.1016/j.ijfoodmicro.2009.02.026

Lu, L., Hume, M. E., and Pillai, S. D. (2004). Autoinducer-2-like activity associated with foods and its interaction with food additives. J. Food Protect. 67, 14571462. doi: 10.4315/0362-028x-67.7.1457

Marchand, S., De Block, J., De Jonghe, V., Coorevits, A., Heyndrickx, M., and Herman, L. (2012). Biofilm formation in milk production and processing environments; influence on milk quality and safety. Comp. Rev. Food Sci. Food Saf. 11, 133-147. doi: 10.1111/j.1541-4337.2011.00183x

Martinez, E., and Campos-Gómez, J. (2016). Oxylipins produced by Pseudomonas aeruginosa promote biofilm formation and virulence. Nat. Commun. 7:13823. doi: $10.1038 /$ ncomms 13823

Martinez, E., Cosnahan, R. K., Wu, M., Gadila, S. K., Quick, E. B., Mobley, J. A., et al. (2019). Oxylipins mediate cell-to-cell communication in Pseudomonas aeruginosa. Commun. Biol. 2:66. doi: 10.1038/s42003-019-0310-0

Mato-Rodriguez, L., and Alatossava, T. (2010). Effects of copper on germination, growth and sporulation of Clostridium tyrobutyricum. Food Microbiol. 27, 434-437. doi: 10.1016/j.fm.2010.01.003

Miller, M. B., and Bassler, B. L. (2001). Quorum sensing in bacteria. Annu. Rev. Microbiol. 55, 165-199. doi: 10.1146/annurev.micro.55.1.165

Miranda, P. S. D., Lannes-Costa, P. S., Pimentel, B. A. S., Silva, L. G., FerreiraCarvalho, B. T., Menezes, G. C., et al. (2018). Biofilm formation on different pH conditions by Streptococcus agalactiae isolated from bovine mastitic milk. Let. Appl. Microbiol. 67, 235-243. doi: 10.1111/lam.13015

Munsch-Alatossava, P., and Alatossava, T. (2006). Phenotypic characterization of raw-milk associated psychrotrophic bacteria. Microbiol. Res. 161, 334-346. doi: 10.1016/j.micres.2005.12.004

Munsch-Alatossava, P., and Alatossava, T. (2007). Antibiotic resistance of raw-milk associated psychrotrophic bacteria. Microbiol. Res. 162, 115-123. doi: 10.1016/ j.micres.2006.01.015

Munsch-Alatossava, P., and Alatossava, T. (2014). Nitrogen gas flushing can be bactericidal: the temperature-dependent destiny of Bacillus weihenstephanensis KBAB4 under a pure N2 atmosphere. Front. Microbiol. 5:619. doi: 10.33889/ fmicb.2014.00619

Munsch-Alatossava, P., Gauchi, J. P., Chamlagain, B., and Alatossava, T. (2012). Trends of antibiotic resistance in mesophilic and psychrotrophic bacterial populations during cold storage of raw milk. ISRN Microbiol. 2012:918208.

Munsch-Alatossava, P., Ghafar, A., and Alatossava, T. (2013). Potential of nitrogen gas (N2) flushing to extend the shelf life of cold stored pasteurised milk. Int. J. Mol. Sci. 14, 5668-5685. doi: 10.3390/ijms14035668

Munsch-Alatossava, P., Gursoy, O., and Alatossava, T. (2010a). Exclusion of phospholipases (PLs)-producing bacteria in raw milk flushed with nitrogen gas (N2). Microbiol. Res. 165, 61-65. doi: 10.1016/j.micres.2008.07.001

Munsch-Alatossava, P., Gursoy, O., and Alatossava, T. (2010b). Improved storage of cold raw milk by continuous flushing of N2 gas separated from compressed air: a pilot scale study. J. Food Process. Technol. 1, 1-4. doi: 10.4172/2157-7110. 1000101

Munsch-Alatossava, P., Gursoy, O., and Alatossava, T. (2010c). Potential of nitrogen gas (N2) to control psychrotrophs and mesophiles in raw milk. Microbiol. Res. 165, 122-132. doi: 10.1016/j.micres.2009.02.002 
Munsch-Alatossava, P., Ibarra, D., Youbi-Idrissi, M., and Alatossava, T. (2019). N2 gas flushing prevents bacteria-promoted lipolysis and proteolysis and alleviates auto-oxidation in bovine raw milk during cold storage. Front. Sust. Food Syst. 3:41. doi: 10.3389/fsufs.2019.00041

Munsch-Alatossava, P., Jääskeläinen, S., Alatossava, T., and Gauchi, J. P. (2017). N2 gas flushing limits the rise of antibiotic-resistant bacteria in bovine raw milk during cold storage. Front. Microbiol. 8:655. doi: 10.3389/fmicb.2017. 00655

Munsch-Alatossava, P., Gursoy, O., Lorilla, P. M., Gauchi, J.-P., and Alatossava, T. (2018b). "Antibacterial effects and modes of action of the activated lactoperoxidase system (LPS), of CO2 and N2 as food-grade approaches to control bovine raw milk-associated bacteria," in Food Control and Biosecurity, eds A. M. Holban and A. M. Grumezescu (Cambridge, MA: Academic Press), 519-541. doi: 10.1016/b978-0-12-811445-2.00015-5

Munsch-Alatossava, P., Käkelä, R., Ibarra, D., Youbi-Idrissi, M., and Alatossava, T. (2018a). Phospholipolysis caused by different types of bacterial phospholipases during cold storage of bovine raw milk is prevented by $\mathrm{N} 2$ gas flushing. Front. Microbiol. 9:1307. doi: 10.3389/fmicb.2018.01307

Munsch-Alatossava, P., Quintyn, R., De Man, I., Alatossava, T., and Gauchi, J. P. (2016). Efficiency of N2 gas flushing compared to the lactoperoxidase system at controlling bacterial growth in bovine raw milk stored at mild temperatures. Front. Microbiol. 7:839. doi: 10.3389/fmicb.2016.00839

Murray, S. K., Kwan, K. K. H., Skura, B. J., and Mc Kellar, R. C. (1983). Effect of nitrogen flushing on the production of proteinase by psychrotrophic bacteria in raw milk. J. Food Sci. 48, 1166-1169. doi: 10.1111/j.1365-2621.1983.tb09 183.x

Mylius, M., Dreesman, J., Pulz, M., Pallasch, G., Beyrer, K., Claußen, K., et al. (2018). Shiga toxin-producing Escherichia coli O103:H2 outbreak in Germany after school trip to Austria due to raw cow milk, 2017- The important role of international collaboration for outbreak investigations. Int. J. Med. Microbiol. 308, 539-544. doi: 10.1016/j.ijmm.2018.05.005

OECD-FAO (2019). "Projections by commodity: dairy and dairy products," in Agricultural Outlook 2019-2028, ed. OECD/FAO (Rome: OECD Publishing Paris/Food and Agriculture Organization of the United Nations).

Olsen, R. H., and Jezeski, J. J. (1963). Some effects of carbon source, aeration, and temperature on growth of a psychrophilic strain of Pseudomonas fluorescens. J. Bacteriol. 86, 429-433. doi: 10.1128/jb.86.3.429-433.1963

Oulahal, N., Martial-Gros, A., Bonneau, M., and Blum, L. J. (2004). Combined effect of chelating agents and ultrasound on biofilm removal from stainless steel surfaces. Application to "Escherichia coli milk" and "Staphylococcus aureus milk” biofilms. Biofilms 1, 65-73. doi: 10.1017/S1479050504001140

Palmer, J., Seale, B., and Flint, S. (2015). "Significance of bacterial attachment: a focus on the food industry," in Biofilms in the Dairy Industry, eds K. H. Teh, S. Flint, J. Brooks, and G. Knight (Hoboken, NJ: Wiley), 17-35. doi: 10.1002/ 9781118876282.ch2

Papenfort, K., and Bassler, B. L. (2016). Quorum sensing signal-response systems in Gram-negative bacteria. Nat. Rev. Microbiol. 14, 576-588. doi: 10.1038/nrmicro. 2016.89

Pasvolsky, R., Zakin, V., Ostrova, I., and Shemesh, M. (2014). Butyric acid released during milk lipolysis triggers biofilm formation of Bacillus species. Int. J. Food Microbiol. 181, 19-27. doi: 10.1016/j.ijfoodmicro.2014.04.013

Paul, T., Jana, A., Das, A., Mandal, A., Halder, S. K., Mohapatra, P. K. D., et al. (2014). Smart cleaning-in-place process through crude keratinase: an ecofriendly cleaning technique towards dairy industries. J. Clean Prod. 76, 140-153. doi: 10.1016/j.jclepro.2014.04.028

Pinto, U. M., De Souza Viana, E., Martins, M. L., and Dantas Vanetti, M. C. (2007). Detection of acylated homoserine lactones in gram-negative proteolytic psychrotrophic bacteria isolated from cooled raw milk. Food Control 18, 13221327. doi: 10.1016/j.foodcont.2006.09.005

Quigley, L., O’Sullivan, O., Stanton, C., Beresford, T. P., Ross, R. P., Fitzgerald, G. F., et al. (2013). The complex microbiota of raw milk. FEMS Microbiol. Rev. 37, 664-698. doi: 10.1111/1574-6976.12030

Raats, D., Offek, M., Minz, D., and Halpern, M. (2011). Molecular analysis of bacterial communities in raw cow milk and the impact of refrigeration on its structure and dynamics. Food Microbiol. 28, 465-471. doi: 10.1016/j.fm.2010. 10.009

Rao, J., DiGiandomenico, A., Artamonov, M., Leitinger, N., Amin, A. R., and Goldberg, J. B. (2011). RahU: an inducible and functionally pleiotropic protein in Pseudomonas aeruginosa modulates innate immunity and inflammation in host cells. Cell Immunol. 270, 103-113. doi: 10.1016/j.cellimm.2011.05.012

Reybroeck, W., De Vleeschouwer, M., Marchand, S., Sinnaeve, D., Heylen, K., De Block, J., et al. (2014). Cyclic lipodepsipeptides produced by Pseudomonas spp. naturally present in raw milk induce inhibitory effects on microbiological inhibitor assays for antibiotic residue screening. PLoS One 9:e98266. doi: 10. 1371/journal.pone.0098266

Rokni-Zadeh, H., Li, W., Sanchez-Rodriguez, A., Sinnaeve, D., Rozenski, J., Martins, J. C., et al. (2012). Genetic and functional characterization of cyclic lipopeptide white- line-inducing principle (WLIP) production by rize rhizosphere isolate Pseudomonas putida RW1052. Appl. Environ. Microbiol. 78, 4826-4834. doi: 10.1128/AEM.00335-12

Rollin, E., Dhuyvetter, K. C., and Overton, M. W. (2015). The cost of clinical mastitis in the first 30 days of lactation: an economic modelling tool. Prev. Vet. Med. 122, 257-264. doi: 10.1016/j.prevetmed.2015.11.006

Schönborn, S., and Krömker, V. (2016). Detection of the biofilm component polysaccharide intercellular adhesin in Staphylococcus aureus infected cow udders. Vet. Microbiol. 196, 126-128. doi: 10.1016/j.vetmic.2016.10.023

Schwartz, K., Ganesan, M., Payne, D. E., Solomon, M. J., and Boles, B. R. (2016). Extracellular DNA facilitates the formation of functional amyloids in Staphylococcus aureus biofilms. Mol. Microbiol. 99, 123-134. doi: 10.1111/mmi. 13219

Shah, N. P. (1994). Psychrotrophs in milk: a review. Milchwissenschaft 49, 432-437.

Shaheen, R., Svensson, B., Andersson, M. A., Christiansson, A., and SalkinojaSalonen, M. (2010). Persistence strategies of Bacillus cereus spores isolated from dairy silo tanks. Food Microbiol. 27, 347-355. doi: 10.1016/j.fm.2009.11.004

Sharma, M., and Anand, S. K. (2002). Characterization of constitutive microflora of biofilms in dairy processing lines. Food Microbiol. 19, 627-636. doi: 10.1006/ fmic.2002.0472

Singh, H., and Bennett, R. J. (2002). "Milk and milk processing," in Dairy Microbiology Handbook, ed. R. K. Robison (New York, NY: Wiley), 1-35.

Singh, H., and Gallier, S. (2017). Nature's complex emulsion: the fat globules of milk. Food Hyd. 68, 81-89. doi: 10.1016/j.foodhyd.2016.10.011

Skandamis, P. N., and Nychas, G.-J. E. (2012). Quorum sensing in the context of food microbiology. Appl. Environ. Microbiol. 78, 5473-5482. doi: 10.1128/AEM. 00468-12

Skura, B. J., Craig, C., and McKellar, R. C. (1986). Effect of disruption of an N2-overlay on growth and proteinase production in milk by Pseudomonas fluorescens. Can. Inst. Food Sci. Technol. J. 19, 104-106. doi: 10.1016/s03155463(86)71462-4

Smith, D. R., Maestre-Reyna, M., Lee, G., Gerard, H., Wang, A. H.-J., and Watnick, P. I. (2015). In situ proteolysis of the Vibrio cholerae matrix protein RbmA promotes biofilm recruitment. PNAS 112, 10491-10496. doi: 10.1073/pnas. 1512424112

Smith, J. L., Fratamico, P. M., and Novak, J. S. (2004). Quorum sensing: a primer for food microbiologists. J. Food Prot. 67, 1053-1070. doi: 10.4315/0362-028x67.5.1053

Sorhaug, T., and Stepaniak, L. (1997). Psychrotrophs and their enzymes in milk and dairy products: quality aspects. Trends Food Sci. Technol. 8, 35-41. doi: 10.1016/s0924-2244(97)01006-6

Sørum, H., and L'Abbé Lund, T. M. (2002). Antibiotic resistance in food-related bacteria-a result of interfering with the global web of bacterial genetics. Int. J. Food Microbiol. 78, 43-56. doi: 10.1016/s0168-1605(02)00241-6

Speers, J. G. S., and Gilmour, A. (1985). The influence of milk and milk components on the attachment of bacteria to farm dairy equipment surfaces. J. App. Bacteriol. 59, 325-332. doi: 10.1111/j.1365-2672.1985.tb03326.x

Spiers, A. J., Bohannon, J., Gehrig, S. M., and Rainey, P. B. (2003). Biofilm formation at the air-liquid interface by the Pseudomonas fluorescens SBW25 wrinkly spreader requires an acetylated form of cellulose. Mol. Microbiol. 50, 15-27. doi: 10.1046/j.1365-2958.2003.03670x

Stenfors Arnesen, L. P., Fagerlund, A., and Granum, P. E. (2008). From soil to gut: Bacillus cereus and its food poisoning toxins. FEMS Microbiol. Rev. 32, 579-606. doi: 10.1111/j.1574-6976.2008.00112x

Subramanian, N., and Qadri, A. (2006). Lysophospholipid sensing triggers secretion of flagellin from pathogenic Salmonella. Nat. Immunol. 7, 583-589. doi: $10.1038 /$ ni1336

Surette, M. G., and Bassler, B. L. (1998). Quorum sensing in Escherichia coli and Salmonella typhimurium. PNAS 95, 7046-7050. doi: 10.1073/pnas.95.12.7046 
Suriyanarayanan, T., Periasamy, S., Lin, M. H., Ishihama, Y., and Swarup, S. (2016). Flagellin FliC phosphorylation affects type 2 protease secretion and biofilm dispersal in Pseudomonas aeruginosa PAO 1. PLoS One 11:e0164155. doi: 10.1371 /journal.pone.0164155

Sustainable Development Goals (2015). United Nation Sustainable GoalsAgenda 2030. Available online at https://www.un.org/sustainabledevelopment/ development-agenda/ (accessed April 7, 2020).

Sutherland, I. W. (2001). Biofilm exopolysaccharides: a strong and sticky framework. Microbiology 147, 3-9. doi: 10.1099/00221287147-1-3

Taylor, M. W., and Mac Gibbon, A. K. H. (2002). "Fatty acids," in Encyclopedia of Dairy Sciences, Vol. 3, eds H. Roginski, J. W. Fuquay, and P. F. Fox (London: Academic Press), 1550-1554.

Teh, K. H., Flint, S., Palmer, J., Andrewes, P., Bremer, P., and Lindsay, D. (2012). Proteolysis produced within biofilms of bacterial isolates from raw milk tankers. Int. J. Food Microbiol. 157, 28-34. doi: 10.1016/j.ijfoodmicro.2012. 04.008

Teh, K. H., Lindsay, D., Palmer, J., Andrewes, P., Bremer, P., and Flint, S. (2013). Lipolysis within single culture and co-culture biofilms of dairy origin. Int. J. Food Microbiol. 163, 129-135. doi: 10.1016/j.ijfoodmicro.2013. 02.009

Tetra Pak (2003). Dairy Processing Handbook, 2nd Revised Edition. Sweden: Tetra Pak Processing Systems Lund.

Turakhia, M. H., and Characklis, W. G. (1989). Activity of Pseudomonas aeruginosa in biofilms: effect of calcium. Biotech. Bioeng. 33, 406-414. doi: 10.1002/bit. 260330405

Van Asselt, E. D., van der Fels-Klerx, H. J., Marvin, H. J. P., van Bockhorst-van de Veen, H., and Nierop Groot, M. (2017). Overview of food safety hazards in the European dairy supply chain. Comp. Rev. Food Sci. Food Saf. 16, 59-75. doi: 10.1111/1541-4337.12245

Varga, L., and Szigeti, J. (2016). Use of ozone in the dairy industry: a review. Int. J. Dairy Technol. 69, 157-168. doi: 10.1111/1471-0307.12302

Varhimo, E., Varmanen, P., Fallarero, A., Skogman, M., Pyörälä, S., Iivanainen, A., et al. (2011). Alpha-and $\beta$-casein components of host milk induce biofilm formation in the mastitis bacterium Streptococcus uberis. Vet. Microbiol. 149, 381-389. doi: 10.1016/j.vetmic.2010.11.010

Verraes, C., Vlaemynck, G., Van Weyenberg, S., De Zutter, L., Daube, G., Sindic, M., et al. (2015). A review of the microbiological hazards of dairy products made from raw milk. Int. Dairy J. 50, 32-44. doi: 10.1016/j.idairyj.2015. 05.011

Vithanage, N. R., Dissanayake, M., Bolge, G., Palombo, E. A., Yeager, T. R., and Datta, N. (2016). Biodiversity of culturable psychrotrophic microbiota in raw milk attributable to refrigeration conditions, seasonality and their spoilage potential. Int. Dairy J. 57, 80-90. doi: 10.1016/j.idairyj.2016.02.042

Walstra, P., Wouters, J. T. M., and Geurts, T. J. (2006). Dairy Science and Technology, 2nd Edn. Boca Raton, FL: CRC Press.

Wichmann, F., Udikovic-Kolic, N., Andrew, S., and Handelsmann, J. (2014). Diverse antibiotic resistance genes in dairy cow manure. mBio 5:e01017. doi: 10.1128/mBio.01017-13

Wijman, J. G. E., De Leeuw, P. P. L. A., Moezelaar, R., Zwietering, M. H., and Abee, T. (2007). Air-liquid interface biofilms of Bacillus cereus: formation, sporulation, and dispersion. Appl. Environ. Microbiol. 73, 1481-1488. doi: 10. 1128/AEM.01781-06

Zhao, Y., Caspers, M. P. M., Metselaar, K. I., De Boer, P., Roeselers, G., Moezelaar, R., et al. (2013). Abiotic and microbiotic factors controlling biofilm formation by thermophilic sporeformers. Appl. Environ. Microbiol. 79, 5652-5660. doi: 10.1128/AEM.00949-13

Conflict of Interest: The authors declare that the research was conducted in the absence of any commercial or financial relationships that could be construed as a potential conflict of interest.

Copyright (c) 2020 Munsch-Alatossava and Alatossava. This is an open-access article distributed under the terms of the Creative Commons Attribution License (CC BY). The use, distribution or reproduction in other forums is permitted, provided the original author(s) and the copyright owner(s) are credited and that the original publication in this journal is cited, in accordance with accepted academic practice. No use, distribution or reproduction is permitted which does not comply with these terms. 